Raf. J. Sci.,Vol.28, No.2 Special Issue for the Third Scientific Conference of Chemistry, pp.37-46, 2019

\title{
Synthesis and Biological Activity of some New Nitrogenous Heterocyclic Compounds Derived from Azachalcone
}

\author{
Munera Y. Roof \\ Department of Chemistry/College of Science Department of Dentistry \\ University of Mosul \\ E-mail: mounerayo@yahoo.com \\ Shakir M. Saied \\ Al-Noor University College \\ E-mail: shakirmsaied@yahoo.com
}

(Received 1/8/2018; Accepted 25/10/2018)

\begin{abstract}
ABCTRACT
A series of heterocyclic compounds containing oxygen and nitrogen atoms, isoxazoline II(a-d) and another containing two nitrogen atoms, pyrazolinesIII(a-d) and phenylpyrazolines IV(a-d) were prepared by the reaction of a proper azachalcones $\mathrm{I}(\mathrm{a}-\mathrm{d})$ with hydroxylaminehydrochloride, hydrazine hydrate or phenylhydrazine. These heterocyclic compounds were characterized by ${ }^{1} \mathrm{H}-\mathrm{NMR}, \mathrm{CHN}$, IR and UV spectra in addition to their some physical properties. Also, these prepared compounds were screened for their biological activities and a theoretical calculation which shows that the product IVa obtained from 1,2 - rout was energetically more stable by $1.3967 \mathrm{kcal} / \mathrm{mole}$ than that came from $1,4-$ rout, thus the reaction proceed via 1,2 - addition.
\end{abstract}

Keywords : azachalcone, isoxazoline, pyrazoline, biological activity.

\section{تحضير والنهالية البليولوجية لبضن المركبل الحلفية الغير المتجلنسة الجية والهشقةمن الازالجاكونلت}

\author{
المانصص \\ يتضمن البحث تحضيرسلسلة من المركبلت الحقي ـة غي ـر المتجان سة الحاوي ـة عل ق ذرة مي اوك سيجين ونت ـروجين

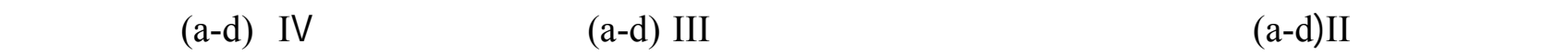

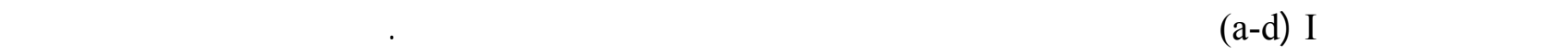

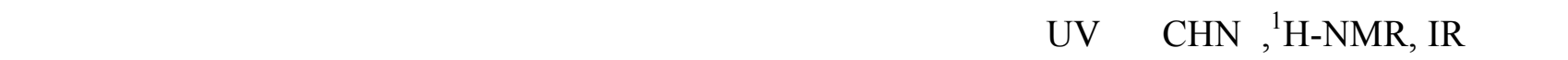 \\ المحضره، كما م مسلب قيم الطاقة للنانج IVa واثبتت ان ميكانيكة الفاعل تقم بميكانيكية إضلفة (1,2). \\ الكاملت الدالة: ازجالكون، ايزوكسازولين، بايرازولين، الفعالية البايولوجية.
}

INTRODUCTION

Study for the improvement of novel biological activity agents is becoming the main importance in many investigate laboratories all over the world with the plan to find out newer, additional effective molecules, with elevated specificity and reduced toxicity than the existing ones(Shih et al., 2018). Five membered rings contain two nitrogen molecules or one nitrogen and other oxygen which were found to be a extremely significant pharmacophore in many therapeutic agents (Gunkara and Ocal, 2018; Rajanarendar et al., 2007). In addition, the incorporation of these moiety into a pharmacologicallyactive pyridyl molecule resulted in many cases in improving the therapeutic profile of the parent 
compound (Abedalazem et al., 2015). Hundreds or even thousands of isooxazoles and pyrazolines nitrogen-containing five-membered heterocyclic compounds have been prepared by many procedures (Gunkara et al., 2018; Patel et al., 2016; Sharma et al., 2014), while pyrazoline derivatives prepared by the addition of hydrazine hydrate or phenylhydrazine to azachalcones, isoxazolines were prepared by the addition of hydroxyl amine hydrochloride to these chalcones (Sharma et al., 2014; Patel et al., 2016; Bhimwal et al., 2011).

These five membered ring nitrogenous or oxygenous heterocyclic derivatives have widespread potential biological activities such as, antimicrobial (Kotla et al., 2012; Hassan et al., 2013), antitumoractivites (Mntoya et al., 2014), antiinflammatory (Venkataraman et al., 2010), antibacterial(Bhimwal et al., 2011; Patel et al., 2016), anticancer agents (Gunkara et al., 2018) and antitubercular activity (Bishnoi et al., 2013). These titles of the heterocyclic compounds appeared of interest to synthesis using azachalcones derivatives as synthons.

\section{EXPERIMENTAL}

Melting points were determined on an electrothermal Stuart melting point SM P30 and were uncorrected. ${ }^{1} \mathrm{H}-\mathrm{NMR}$ spectra of some synthesized compounds were recorded on NMReady 60 ProUser Manual/Version 1.0 at central service laboratory, University of Baghdad. The chemical shifts are reported in $\delta$ values (ppm) relative to tetramethylsilane and quoted as $s$ (singlet), $d$ (doublet), $t$ (triplet), $b r$ (broad) and $m$ (multiplet). Infrared absorption spectra were recorded on Bruker spectrophotometer from college of Pharmacy, University of Mosul. Elemental analysis (CHN) obtained via EuroEA3000/Italy Elemental analyzer from the central service laboratory, University of Baghdad. Ultra-Violet spectra (UV spectra) obtained via Spectro UV-Vis Auto,UV-2602, from college of Agriculture, University of Mosul. All heterocyclic products II(a-d), III(a-d) and IV(a-d) have been tested for their biological activity at college of Sciences-Mosul University, through agar diffusion method.

The starting azachalcones (3-(pyridine-2-yl)-1-(p-tolyl,bromo, chloro or fluro)prop-2-en-1-one) I(a-d) were prepared according to a previous work (Raoof, 2005).

Synthesis of 3-(4-substituted phenyl)-5-(2 -pyridyl)-4,5-dihydro isoxazoline II(a-d)(Joshi et al., 2012) :

Equimolar mixture of aproper azachalcones $1(\mathrm{a}-\mathrm{d})(2.5 \mathrm{mmol})$, hydroxylamine hydrochloride $(2.5 \mathrm{mmol}, 0.17 \mathrm{gm})$ and sodium acetate $(2.5 \mathrm{mmol}, 0.21 \mathrm{gm})$ in ethanol $(20 \mathrm{ml})$ is refluxed for 6-7 hours. The mixture was concentrated under atmospheric pressure, then poured into ice water. The precipitates obtained were filtered off, washed with water and crystallized with suitable solvent to afford a solid compounds II(a-d). Tables (1and 2) show some physical properties and spectral data of these compounds respectively:

Table 1: Physical properties of compounds II(a-d)

\begin{tabular}{|c|c|c|c|c|c|c|}
\hline $\begin{array}{c}\text { Compd. } \\
\text { No.II }\end{array}$ & $\mathbf{R}$ & $\begin{array}{c}\text { Solvent of } \\
\text { crystallization }\end{array}$ & $\begin{array}{c}\text { M.P. } \\
\mathbf{C}^{\circ}\end{array}$ & $\begin{array}{c}\text { Yield } \\
\mathbf{\%}\end{array}$ & color & Molecular formula \\
\hline $\mathrm{a}$ & $\mathrm{CH}_{3}$ & Ether & $139-141$ & 33 & yellow & $\mathrm{C}_{15} \mathrm{H}_{14} \mathrm{~N}_{2} \mathrm{O}$ \\
\hline $\mathrm{b}$ & $\mathrm{Br}$ & EtOH-H $\mathrm{H}_{2} \mathrm{O}$ & $152-156$ & 70 & brown & $\mathrm{C}_{14} \mathrm{H}_{11} \mathrm{~N}_{2} \mathrm{OBr}$ \\
\hline $\mathrm{c}$ & $\mathrm{Cl}$ & Benzene & $136-139$ & 29 & yellow & $\mathrm{C}_{14} \mathrm{H}_{11} \mathrm{~N}_{2} \mathrm{OCl}$ \\
\hline $\mathrm{d}$ & $\mathrm{F}$ & $\mathrm{EtOH}$ & $130($ dec.). & 19 & brown & $\mathrm{C}_{14} \mathrm{H}_{11} \mathrm{~N}_{2} \mathrm{OF}$ \\
\hline
\end{tabular}


Table 2: Spectral data of compounds II(a-d)

\begin{tabular}{|c|c|c|c|c|c|c|c|c|}
\hline \multirow{2}{*}{$\begin{array}{l}\text { Compd. } \\
\text { No.II }\end{array}$} & \multirow{2}{*}{$\mathbf{R}$} & \multirow{2}{*}{$\begin{array}{c}\mathrm{UV}\left(\mathrm{CHCl}_{3}\right) \\
\lambda_{\text {max. }} \mathbf{n m}\end{array}$} & \multirow{2}{*}{\multicolumn{3}{|c|}{$\mathrm{IR}(\mathrm{KBr}) \mathrm{cm}^{-1}$}} & \multirow{2}{*}{$\begin{array}{c}{ }^{1} \text { H-NMR } \\
\text { (DMSO) } \delta \text {-ppm }\end{array}$} & \multicolumn{2}{|c|}{ CHN } \\
\hline & & & & & & & Calculated & Found \\
\hline $\mathrm{a}$ & $\mathrm{CH}_{3}$ & 275 & $\begin{array}{l}3034 \\
1667 \\
1123\end{array}$ & $\begin{array}{l}\mathrm{CH}_{\text {arom.; }} \\
\mathrm{C}=\mathrm{N} ; \\
\mathrm{C}-\mathrm{O}\end{array}$ & $\begin{array}{l}2920 \text { C- } \\
1587\end{array}$ & $\begin{array}{c}6.65-7.68(\mathrm{~m}), 8 \mathrm{H} \\
5.27-5.58(\mathrm{~m}), 1 \mathrm{H} \\
3.65-4.15(\mathrm{db}), 1 \mathrm{H} \\
2.94(\mathrm{~d}), 1 \mathrm{H} \\
2.29(\mathrm{~s}), 3 \mathrm{H}\end{array}$ & $\begin{array}{cc}\mathrm{C} & 75.6 \\
\mathrm{H} & 5.9 \\
\mathrm{~N} & 11.7\end{array}$ & $\begin{array}{c}78.7 \\
5.6 \\
12.8\end{array}$ \\
\hline $\mathrm{b}$ & $\mathrm{Br}$ & 268 & $\begin{array}{l}3054 \\
1678 \\
1056\end{array}$ & $\begin{array}{l}\mathrm{CH}_{\text {arom. }} \\
\mathrm{C}=\mathrm{N} ; \\
\mathrm{C}-\mathrm{O}\end{array}$ & $\begin{array}{l}2999 \\
1582 \\
\end{array}$ & & & \\
\hline $\mathrm{c}$ & $\mathrm{Cl}$ & 268 & $\begin{array}{l}3107 \\
1675 \\
1048\end{array}$ & $\begin{array}{l}\mathrm{CH}_{\text {arom.; }} \\
\mathrm{C}=\mathrm{N} ; \\
\mathrm{C}-\mathrm{O}\end{array}$ & $\begin{array}{r}2717 \\
1587\end{array}$ & $\begin{array}{r}7.07-8.44 \\
4.95-5.39(\mathrm{t}), 1 \mathrm{H} \\
2.70-3.06(\mathrm{~m}), 2 \mathrm{H}\end{array}$ & $\begin{array}{cc}\mathrm{C} & 65 \\
\mathrm{H} & 4.2 \\
\mathrm{~N} & 10.8\end{array}$ & $\begin{array}{l}60.8 \\
4.28 \\
8.57\end{array}$ \\
\hline $\mathrm{d}$ & $\mathrm{F}$ & 290 & $\begin{array}{l}3131 \\
1682 \\
1093\end{array}$ & $\begin{array}{l}\mathrm{CH}_{\text {arom.; }} \\
\mathrm{C}=\mathrm{N} ; \\
\mathrm{C}-\mathrm{O}\end{array}$ & $\begin{array}{r}2820 \\
1544 \\
\end{array}$ & & & \\
\hline
\end{tabular}

Synthesis of [3-(4-substituted phenyl )-5-(2 -pyridyl)]-4,5-dihydro pyrazolines III(a-d) (Chincholkar et al., 1979; Venkataraman et al., 2010):

A mixture of a proper azachalcone $(2.5 \mathrm{mmol})$, hydrazine hydrate $(5 \mathrm{mmol}, 0.25 \mathrm{gm})$, either in pyridine to prepare compounds III(a and b)(method A), or in ethanol to prepare compounds III(c and d)(method B) was refluxed for 6-7 hrs. The mixture was poured into ice water, the precipitate formed washed with water, dried and crystallized with suitable solvent to afford amorphous solid of compounds III(a-d). Tables (3 and 4) showed some physical properties and spectral data of these compounds respectively.

Table 3: Physical properties of compounds III(a-d)

\begin{tabular}{|c|c|c|c|c|c|c|}
\hline $\begin{array}{c}\text { Compd. } \\
\text { No.III }\end{array}$ & $\mathbf{R}$ & $\begin{array}{c}\text { Solvent of } \\
\text { crystallization }\end{array}$ & $\begin{array}{c}\text { M.P. } \\
\mathbf{C}^{\circ}\end{array}$ & $\begin{array}{c}\text { Yield } \\
\mathbf{\%}\end{array}$ & color & $\begin{array}{c}\text { Molecular } \\
\text { formula }\end{array}$ \\
\hline $\mathrm{a}$ & $\mathrm{CH}_{3}$ & EtOH- $\mathrm{H}_{2} \mathrm{O}$ & $\begin{array}{c}75-80 \\
\text { decomp. }\end{array}$ & 30 & brown & $\mathrm{C}_{15} \mathrm{H}_{15} \mathrm{~N}_{3}$ \\
\hline $\mathrm{b}$ & $\mathrm{Br}$ & $\mathrm{EtOH}$ & $152-155$ & 28 & yellow & $\mathrm{C}_{14} \mathrm{H}_{12} \mathrm{~N}_{3} \mathrm{Br}$ \\
\hline c & $\mathrm{Cl}$ & Ether & $\begin{array}{c}101-110 \\
\text { decomp. }\end{array}$ & 28 & brown & $\mathrm{C}_{14} \mathrm{H}_{12} \mathrm{~N}_{3} \mathrm{Cl}$ \\
\hline d & $\mathrm{F}$ & EtOH- $\mathrm{H}_{2} \mathrm{O}$ & $\begin{array}{c}67-70 \\
\text { decomp. }\end{array}$ & 25 & yellow & $\mathrm{C}_{14} \mathrm{H}_{12} \mathrm{~N}_{3} \mathrm{~F}$ \\
\hline
\end{tabular}


Table 4 : Spectral data of compounds III(a-d)

\begin{tabular}{|c|c|c|c|c|c|c|}
\hline \multirow{2}{*}{$\begin{array}{l}\text { Compd. } \\
\text { No.III }\end{array}$} & \multirow{2}{*}{$\mathbf{R}$} & \multirow{2}{*}{$\begin{array}{c}\mathrm{UV}\left(\mathrm{CHCl}_{3}\right) \\
\lambda_{\text {max. }} \mathrm{nm}\end{array}$} & \multirow{2}{*}{$\operatorname{IR}(\mathrm{KBr}) \mathrm{cm}^{-1}$} & \multirow{2}{*}{$\begin{array}{c}{ }^{1} \text { H-NMR } \\
\text { (DMSO) } \delta-p p m\end{array}$} & \multicolumn{2}{|c|}{ CHN } \\
\hline & & & & & calculated & Found \\
\hline $\mathrm{a}$ & $\mathrm{CH}_{3}$ & 260 & $\begin{array}{llll}3270 & \mathrm{NH} ; & 3020 & \mathrm{CH}_{\text {arom.; }} \\
2870 & \mathrm{C} \mathrm{H}_{\text {alip }} & 1660 & \mathrm{C}=\mathrm{N} \\
1560 & \mathrm{C}=\mathrm{C}_{\text {arom; }} & 1310 & \mathrm{C}-\mathrm{N}\end{array}$ & $\begin{array}{c}8.53-8.44(\mathrm{br}), 1 \mathrm{H} ; \\
\text { 7.91-7.34(m),8H; } \\
\text { 4.25(m),1H; } \\
3.69(\mathrm{db}), 2 \mathrm{H} ; \\
2.51(\mathrm{~s}), 3 \mathrm{H}\end{array}$ & $\begin{array}{lc}\mathrm{C} & 75.9 \\
\mathrm{H} & 6.3 \\
\mathrm{~N} & 17.7\end{array}$ & $\begin{array}{c}74 \\
5.8 \\
16.2\end{array}$ \\
\hline $\mathrm{b}$ & $\mathrm{Br}$ & 280 & $\begin{array}{lll}3210 & \mathrm{NH} & 3055 \quad \mathrm{CH}_{\text {arom.; }} ; \\
2905 & \mathrm{CH}_{\text {aliph; }} ; 1677 \quad \mathrm{C}=\mathrm{N} ; \\
1584 & \mathrm{C}=\mathrm{C}_{\text {arom } ;} ; 285 \quad \mathrm{C}-\mathrm{N}\end{array}$ & $\begin{array}{c}8.52-8.45(\mathrm{br}), 1 \mathrm{H} \\
8.11-7.40(\mathrm{~m}), 8 \mathrm{H} \\
3.80(\mathrm{~m}), 1 \mathrm{H} \\
3.60-3.52(\mathrm{db}), 2 \mathrm{H}\end{array}$ & $\begin{array}{lc}\mathrm{C} & 55.6 \\
\mathrm{H} & 4.0 \\
\mathrm{~N} & 13.9\end{array}$ & $\begin{array}{c}52.4 \\
3.5 \\
12.75\end{array}$ \\
\hline $\mathrm{c}$ & $\mathrm{Cl}$ & 300 & $\begin{array}{l}3462 \mathrm{NH} \quad 3020 \mathrm{CH}_{\text {arom. }} \\
2900 \mathrm{CH}_{\text {aliph. }} 1685 \mathrm{C}=\mathrm{N} \\
1604 \mathrm{C}^{-\mathrm{C}_{\text {arom. }}} 1375 \mathrm{C}-\mathrm{N}\end{array}$ & & & \\
\hline d & $\mathrm{F}$ & 288 & $\begin{array}{llll}3413 & \mathrm{NH} ; & 3078 \mathrm{CH}_{\text {arom. }} \\
2850 & \mathrm{CH}_{\text {aliph. }} & 1601 \mathrm{C}=\mathrm{N} \\
1508 & \mathrm{C}=\mathrm{C}_{\text {arom, }} & 1232 \mathrm{C}-\mathrm{N}\end{array}$ & & & \\
\hline
\end{tabular}

Synthesis of 1-phenyl[3-(4-substituted phenyl)-5-(2 -pyridyl)]-4,5-dihydro pyrazoline IV(a-d): (Sharma et al., 2014)

A mixture of proper azachalcones $(2.5 \mathrm{~mol})$, phenyl hydrazine $(2.5 \mathrm{~mol}, 0.27 \mathrm{gm})$ and $10 \mathrm{ml}$ glacial acetic acid was refluxed for 3-4 hrs., the mixture was then poured into ice-water. The residue was filtered off, washed with water, dried and crystallized from suitable solvent to afford a solid compounds IV(a-d). Tables(5 and 6) showed some physical properties and spectral data respectively of these compounds.

Table 5 : Some physical properties of compounds IV(a-d)

\begin{tabular}{|c|c|c|c|c|c|c|}
\hline $\begin{array}{c}\text { Compd. } \\
\text { No.IV }\end{array}$ & $\mathbf{R}$ & $\begin{array}{c}\text { Solvent of } \\
\text { crystallization }\end{array}$ & $\begin{array}{c}\text { M.P. } \\
\mathbf{C}^{\circ}\end{array}$ & $\begin{array}{c}\text { Yield } \\
\text { \% }\end{array}$ & color & $\begin{array}{c}\text { Molecular } \\
\text { formula }\end{array}$ \\
\hline $\mathrm{a}$ & $\mathrm{CH}_{3}$ & $\mathrm{EtOH}$ & $118-119$ & 35 & white & $\mathrm{C}_{21} \mathrm{H}_{19} \mathrm{~N}_{3}$ \\
\hline $\mathrm{b}$ & $\mathrm{Br}$ & $\mathrm{EtOH}$ & $155-159$ & 25 & yellow & $\mathrm{C}_{20} \mathrm{H}_{16} \mathrm{~N}_{3} \mathrm{Br}$ \\
\hline $\mathrm{c}$ & $\mathrm{Cl}$ & $\mathrm{EtOH}$ & $138-140$ & 30 & yellow & $\mathrm{C}_{20} \mathrm{H}_{16} \mathrm{~N}_{3} \mathrm{Cl}$ \\
\hline $\mathrm{d}$ & $\mathrm{F}$ & $(\mathrm{Me})_{2} \mathrm{O}$ & $158-162$ & 18 & yellow & $\mathrm{C}_{20} \mathrm{H}_{16} \mathrm{~N}_{3} \mathrm{~F}$ \\
\hline
\end{tabular}


Table 6: Spectral data of compounds IV(a-d)

\begin{tabular}{|c|c|c|c|c|c|c|}
\hline \multirow{2}{*}{$\begin{array}{l}\text { Compd. } \\
\text { No.IV }\end{array}$} & \multirow{2}{*}{$\mathbf{R}$} & \multirow{2}{*}{$\begin{array}{c}\mathrm{UV}\left(\mathrm{CHCl}_{3}\right) \\
\lambda_{\max } . \mathrm{nm}\end{array}$} & \multirow[t]{2}{*}{$\operatorname{IR}(\mathrm{KBr}) \mathrm{cm}^{-1}$} & \multirow{2}{*}{$\begin{array}{c}{ }^{1} \text { H-NMR } \\
\text { (DMSO) } \delta \text {-ppm }\end{array}$} & \multicolumn{2}{|c|}{ CHN } \\
\hline & & & & & calculated & Found \\
\hline $\mathrm{a}$ & $\mathrm{CH}_{3}$ & 258 & $\begin{array}{c}3127 \mathrm{CH}_{\text {arom. }} 2833 \mathrm{CH}_{\text {alip }} \\
1598 \mathrm{C}=\mathrm{N} ; 1512 \mathrm{C}=\mathrm{C}_{\text {arom }} \\
1332 \mathrm{C}-\mathrm{N}\end{array}$ & $\begin{array}{c}7.32-8.53(\mathrm{~m}), 13 \mathrm{H} \\
5.47-5.81(\mathrm{t}), 1 \mathrm{H} \\
3.05-4.26(\mathrm{~m}), 2 \mathrm{H} \\
2.80(\mathrm{~s}), 3 \mathrm{H}\end{array}$ & $\begin{array}{ll}\mathrm{C} & 80.5 \\
\mathrm{H} & 6.07 \\
\mathrm{~N} & 13.4\end{array}$ & $\begin{array}{l}77.0 \\
6.11 \\
10.3\end{array}$ \\
\hline $\mathrm{b}$ & $\mathrm{Br}$ & 290 & $\begin{array}{c}3015 \mathrm{CH}_{\text {arom. }} 2920 \mathrm{H}_{\text {aliph. }} \\
1630 \mathrm{C}=\mathrm{N} ; 1550 \mathrm{C}=\mathrm{C}_{\text {arom. }} \\
1358 \mathrm{C}-\mathrm{N}\end{array}$ & & & \\
\hline $\mathrm{c}$ & $\mathrm{Cl}$ & 260 & $\begin{array}{c}3050 \mathrm{CH}_{\text {arom.; }} 2900 \mathrm{CH}_{\text {aliph. }} \\
1589 \mathrm{C}=\mathrm{N} ; \\
\mathrm{C}_{\text {arom. }} 1319 \mathrm{C}-\mathrm{N}\end{array}$ & $\begin{array}{c}6.67-7.80(\mathrm{~m}), 13 \mathrm{H} \\
5.33-5.64(\mathrm{~m}), 1 \mathrm{H} \\
2.96-4.16(\mathrm{~m}), 2 \mathrm{H}\end{array}$ & $\begin{array}{cc}\mathrm{C} & 72.1 \\
\mathrm{H} & 4.8 \\
\mathrm{~N} & 12.6\end{array}$ & $\begin{array}{c}72.13 \\
4.8 \\
12.3\end{array}$ \\
\hline d & $\mathrm{F}$ & 278 & $\begin{array}{c}3046 \mathrm{CH}_{\text {arom. }} ; 2857 \mathrm{CH}_{\text {aliph.; }} \\
1593 \mathrm{C}=\mathrm{N} ; 1549 \\
\mathrm{C}=\mathrm{C}_{\text {arom.; }} \\
1238 \mathrm{C}-\mathrm{N}\end{array}$ & & & \\
\hline
\end{tabular}

BIOLOGICAL ACTIVITY

The procedure followed for tested the titles heterocyclic products is simply that a filter disk impregnated with an antibiotic which is applied to the surface of anagar plate containing the organism to be tested and the plate is incubated at $37^{\circ} \mathrm{C}$ for $24-48$ hours. AS the substance diffuses from the filter paper into the agar, the concentration decreases. At some particular distance from each disk, the antibiotic is diluted to the point that is no longer inhibits microbial growth. The effectiveness of particular antibiotic is shown by the presence of growth inhibition zones. These zones appear as clear areas surrounding the disk from the substances with antimicrobial activity. Measur the zone sizes to the nearest millimeter using a ruler and the results reported as $(++),(+),( \pm)$ or $(-)$, Table(7). Dimethyl sulfoxide (DMSO) was used as a solvent for the compounds, blank paper disk of DMSO also was used as control.

Table 7 : Biological activity for products (II-IV)

\begin{tabular}{|c|c|c|c|}
\hline Comp.No. & E-coli & Staphylococcus-aureus & Pseudomonas-aeruginosa \\
\hline IIa & ++ & \pm & - \\
\hline IIb & - & - & - \\
\hline IIc & + & + & - \\
\hline IId & + & + & - \\
\hline IIIa & ++ & + & - \\
\hline IIIb & + & + & - \\
\hline IIIc & - & + & - \\
\hline IIId & \pm & + & - \\
\hline IVa & + & + & - \\
\hline IVb & + & - & - \\
\hline IVc & - & + & - \\
\hline IVd & \pm & - & $5-100 m$ \\
\hline
\end{tabular}

Note: $(++)=$ sensitive, more than $20 \mathrm{~mm},(+)=$ intermediate, $10-20 \mathrm{~mm},( \pm)=$ weak, $\quad 5-10 \mathrm{~mm},(-)=$ resistant, no inhibition, 


\section{RESULS AND DISCUSSION}

A suitable synthesis of aimed heterocyclic compounds were accomplished by the route outlined in Scheme (1) :
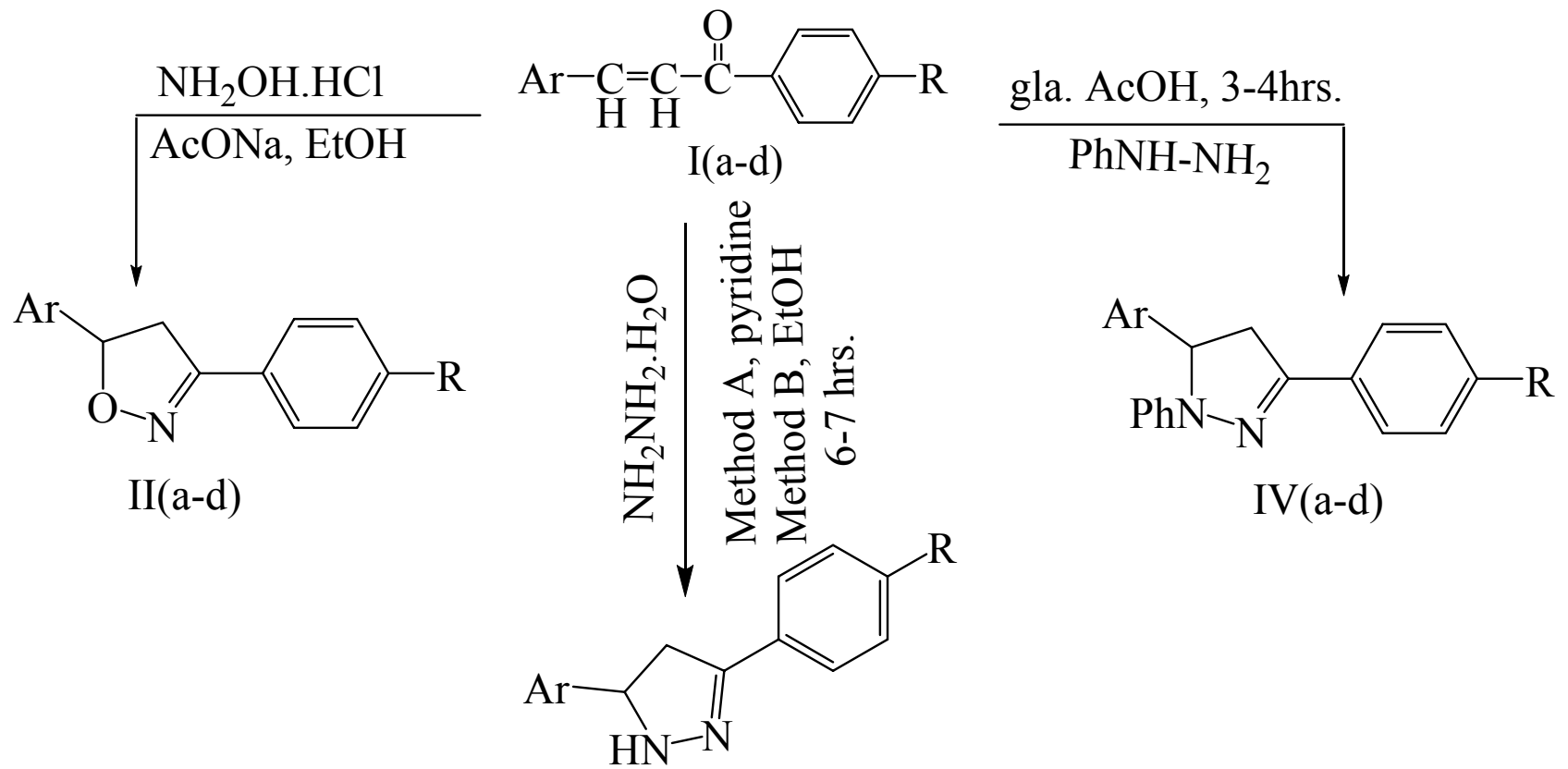

III

$$
\text { (a-b) Method A }
$$$$
\mathrm{R}=\mathrm{CH}_{3}, \mathrm{Br}, \mathrm{Cl}, \mathrm{F}
$$

\section{Scheme 1: Synthesis heterocyclic compounds containing N,O or N, N-atoms}

In this work, the synthesis of isoxazolines II(a-d) from the cyclization of starting azachalcones and hydroxylamine hydrochloride was carried out as shown in Scheme (1). In order to achieve this aim, sodium acetate as a base was used.

The nucleophile $\left(\mathrm{HONH}_{2}\right)$ attack carbon number (4) of $\alpha, \beta$-unsaturated carbonyl compound via 1,4 - Michael addition giving intermediate (A) which cyclized via intermolecular addition to produce intermediate (B), the driving force for ring formation was the water elimination (Raoof et al., 2013; Levai, 2005; Levai et al., 2007). The proposed mechanism was illustrated in Scheme (2) (Shah and Desai, 2007) : 


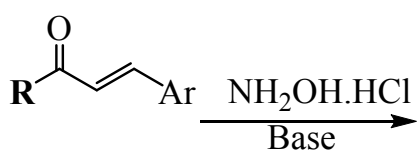

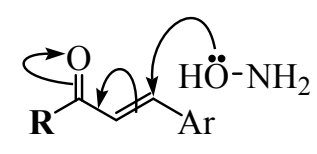

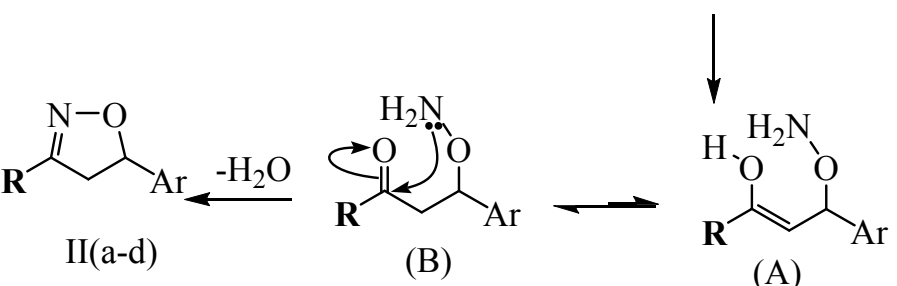

(A)

\section{Scheme 2: The preposed mechanism for cyclization}

The UV spectral data for the products II(a-d) showed a blue shift in $\lambda_{\max }$ values (268-290), indicating that these products was less conjugated than staring materials (Raoof, 2005). The IR spectra of these products showed the major absorption band at $(1667-1682) \mathrm{cm}^{-1}$ for $\mathrm{C}=\mathrm{N}$, (Azarifar and Shaebanzadeh, 2002; Daood and Ahmed, 2015; Bhimwal et al., 2011). Other absorption bands were represented in Table (2). The ${ }^{1} \mathrm{H}-\mathrm{NMR}$ spectra of compounds (IIa and c) were in agreements with the suggested structures. For the product IIa appeared signals at: $\delta(6.65-8.54) \mathrm{ppm}(\mathrm{m}, 8 \mathrm{H}$, Aryl and Pyridyl-H), (5.27-5.58)ppm ( $\mathrm{m}, 1 \mathrm{H}, \mathrm{CH}$ oxazoline ring), (3.65-4.15)ppm (db, 1H, $\mathrm{CH}_{2}$ oxazoline ring), 2,9ppm (db, 1H, $\mathrm{CH}_{2}$ oxazoline ring)and $2.29 \mathrm{ppm}\left(\mathrm{s}, 3 \mathrm{H}, \mathrm{CH}_{3}\right)$, (Shah et al., 2007), while compound IIc appeared as signals at: $\delta(7.07-8.44) \mathrm{ppm}(\mathrm{m}, 8 \mathrm{H}$, Aryl and Pyridyl-H), (4.95-5.39) ppm (t, $1 \mathrm{H}, \mathrm{CH}$ oxazoline ring) and (2.70-3.06) ppm $\left(\mathrm{m}, 2 \mathrm{H}, \mathrm{CH}_{2}\right.$ oxazoline ring). The elemental analysis calculated for the product (IIa) $\mathrm{C}_{15} \mathrm{H}_{14} \mathrm{~N}_{2} \mathrm{O}(\%)$ : C,75.6; H,5.9; N,11.7; found: C,78.7; H,5.6; N,12.8 and for the product (IIc) $\mathrm{C}_{14} \mathrm{H}_{11} \mathrm{~N}_{2} \mathrm{OCl}(\%)$ : C,65; H,4.2; N,10.8; found: $\mathrm{C}, 60.8 ; \mathrm{H}, 4.27 ; \mathrm{N}, 8.57$. It should be noted that the results of the CHN analyses are affected by many contaminants present in the sample like, (moisture, solvent, dust). Therefore, the values determined experimentally might not correspond to the theoretical values (Swamy and Agasimundi, 2008; Arora et al., 2012).

Reaction of azachalcones I(a-d) with hydrazine hydrate using pyridine (method A) or ethanol (method B) gave pyrazoline derivatives III( $a-b$ and $c-d)$ respectively. The mechanism is the same as suggested for synthesis of compounds II as shown by Scheme (2).

The UV spectral data show a blue shift in $\lambda_{\max }$ values (260-300), indicating that these products are less conjugated than starting materials and the reaction take place. The IR spectra showed absorptions bands at (3210-3462) $\mathrm{cm}^{-1}$ and (1601-1685) $\mathrm{cm}^{-1}$ for $\mathrm{NH}$ and $\mathrm{C}=\mathrm{N}$ respectively, (Table 4). The ${ }^{1} \mathrm{H}-$ NMR spectra of compounds III(a and b) gave signals at (8.52-8.44) ppm (br, 1H, NH), (Shah et al., 2007), (8.11-7.34)ppm (m., 8H, Aryl and Pyridyl-H), (4.25-3.80)ppm (m, 1H, CH pyrazoline ring) and (3.69-3.52)ppm(db, 2H, $\mathrm{CH}_{2}$ pyrazoline ring). The compound IIIa gave an additional signal at

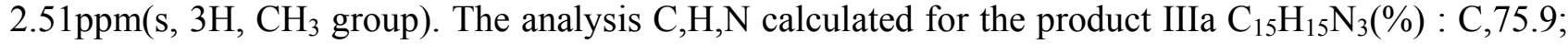
$\mathrm{H}, 6.3$; N,17.7; found : C,74.3; H5.8; N,16.2, while for the product IIIb $\mathrm{C}_{14} \mathrm{H}_{12} \mathrm{~N}_{3} \mathrm{Br}(\%)$ : C,55.6; H,4; $\mathrm{N}, 13.9$; found : C,52.4; H,3.5; N,12.7.

Unfortunately, the yield of these compounds are low, these results can be attributed to the ability of the $\mathrm{N}$ - unsubstituted pyrazoline molecule to form an intermolecular hydrogen bonding, which can lead to at least five motifs such as dimers trimers and tetramers as the following (Ahmed, 2011): 
<smiles></smiles>

dimer<smiles></smiles>

trimer

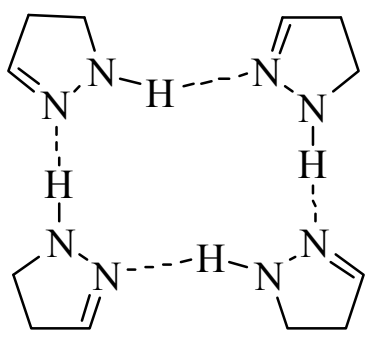

tetramer

Phenylpyrazoline derivatives IV(a-d) obtained by the addition of phenylhydrazine to the proper acceptor (activated $\alpha, \beta$-unsaturated carbonyl compounds) through 1,4- conjugate addition or at the carbonyl carbon 1,2 - addition to form intermediate, which then undergoes cyclization process to form the product, Scheme (3).

Theoretical calculations (for product IVa which choosed as representative for these serious) showed that the product obtained from 1,2 - rout was energetically more stable by $1.3967 \mathrm{kcal} / \mathrm{mole}$ than that came from 1,4-rout; thus, we suggest that reaction proceed via 1,2-addition (Al-Kadhimi et al.,2013):

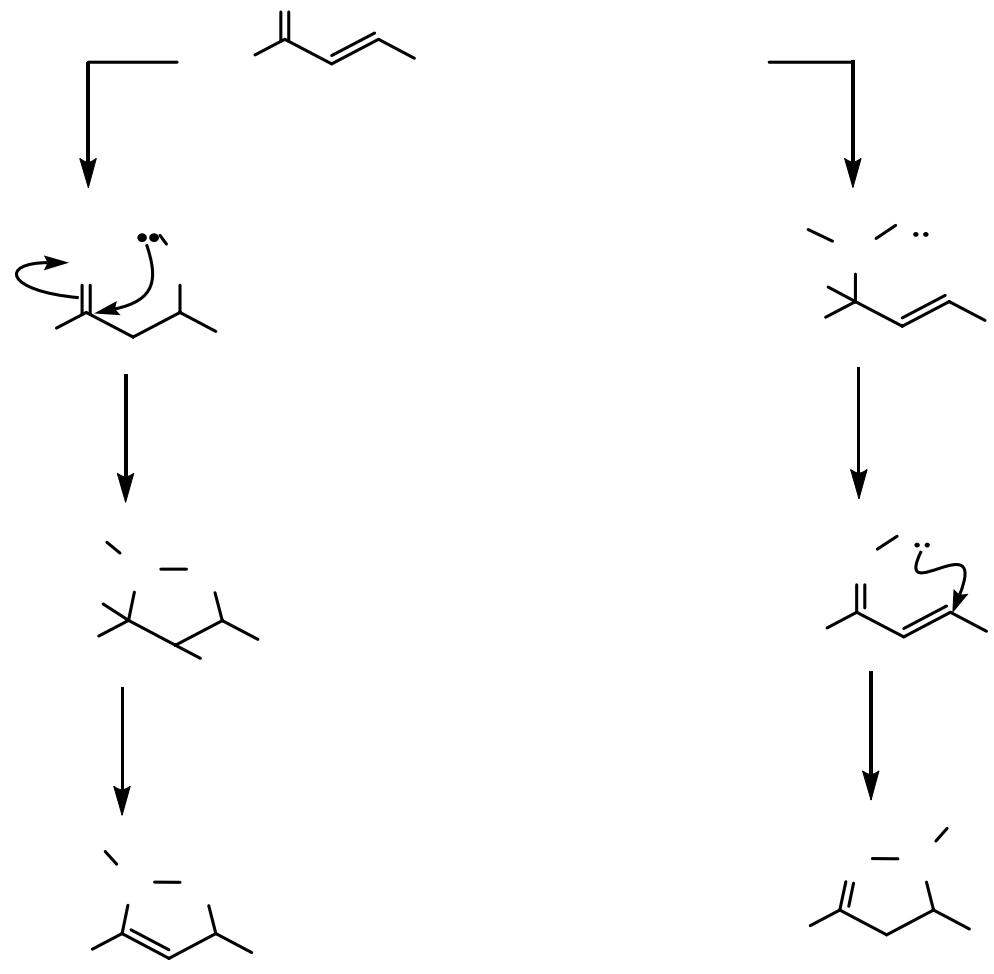

Scheme 3: mechanism of 1,4 and 1,2 addition 
The UV spectral data show a blue shift in $\lambda_{\max }$ values $(258-290) \mathrm{nm}$. the IR spectra showed the most important absorption band at $(1589-1630) \mathrm{cm}^{-1}$ belong to $\mathrm{C}=\mathrm{N}$ stretching, (Al-Kadhimi et al., 2013), (Table 6). The ${ }^{1} \mathrm{H}-\mathrm{NMR}$ spectra of compounds IV (a and c) appeared signals at : $\delta(8.53-$ 6.67)ppm (m,13H, Aryl and Pyridyl-H), (4.95-5.81)ppm (m, 1H, CH pyrazoline ring)) and (2.964.26)ppm ( $\mathrm{m}, 2 \mathrm{H}, \mathrm{CH}_{2}$ pyrazoline ring). The product IVa gives additional signal at $2.80 \mathrm{ppm}(\mathrm{s}, 3 \mathrm{H}$, $\left.\mathrm{CH}_{3}\right)$. The analysis $\mathrm{C}, \mathrm{H}, \mathrm{N}$ calculated for the product $\mathrm{IVa}_{21} \mathrm{H}_{19} \mathrm{~N}_{3}(\%): \mathrm{C}, 80.5 ; \mathrm{H}, 6.07 ; \mathrm{N}, 13.4$; found : C,77.3; H.6.11; N,10.3, while for the product (IVc) $\mathrm{C}_{20} \mathrm{H}_{16} \mathrm{~N}_{3} \mathrm{Cl}(\%)$ : C,72.1; H,4.8; N,12.6; found : $\mathrm{C}, 72.13 ; \mathrm{H}, 4.8 ; \mathrm{N}, 12.3$.

Antimicrobial activity of the prepared compounds II, III, IV(a-d) was examined by the agar diffusion method used free different bacterial species, i.e. E-Coli, Staphylococcus aureus and Pseudomonas aeruginosa. The prepared compounds show higher activity towards E. coli and Staph. aureus compared to the pseudomonas aeruginosa, (Table 7) (Nowakowska et al., 2001).

\section{ACKNOWLEDGMENT}

The authors are thankful to Ms. Shbaba /College of Science - Biological department for the biological screening of the preparing compounds.

\section{REFERENCES}

Abdelazem, A.Z.; Lee, S.H. (2015). Synthesis and biological evaluation of new pyrimidine-4-ylethanol derivatives as ROS1 kinase inhibitors. J.Enzyme Inhibition and Midic. Chem., 90, 195208.

Ahmed, S.A.Q.S. (2011). Synthesis of various heterocyclic compounds from $\alpha, \beta$-unsaturated ketones. M.Sc. Thesis, College of Scince. Mosul University.

Al-Kadhimi, A.H.; Al-Khayate, A.K.; Al-Dulyme, M.G. (2013). Synthesis and characterization of some new pyrazoline derivatives from chalcones bearing benzofurane moiety. The First Scie. Conference the College of Sciences,pp.283-292 www.iasj.net/iasj?func=f.

Arora, V.; Arora, P.; Lamba, H.S.(2012). Synthesis and biological activities of some 3,5- disubstituted pyrazoline derivatives of 2- acetyl naphthalene. International J. Pharm. and Pharmaceut. Sci., 4(4),2012.

Azarifar, D.; Shaebanzadeh, M. (2002). Synthesis and characterization of new 3,5-dinaphthyl substituted 2-pyrazolines and study of their antimicrobial activity. J. Molecules,7(12),885-895.

Bhimwal, R.; Sharma, A.K.; Jain, A. (2011). Synthesis, characterization and In-vitro antimicrobial evaluation of some novel isoxazoline derivatives. J. Advanced Pharm. Education and Research, 1(5), 251-258.

Bishinoi, A.; Singh, S.; Tiwari, A.K.; Srivastava, K.; Raghuvir, R.; Tripathi, C.M. (2013). Synthesis, characterization and biological activity of new cyclization products of 3-(4-substituted benzylidene-2H-pyrido [1,2-a] pyrmidine-2,4-(3H)-diones. J.Chem. Sci., 125(2), 305-312.

Chincholkar, M.M.; Jamode, V.S. (1979). Synthesis of pyrazoline Part II, 72p. Shodhganga. inflibnet.ac.in/bitstream.

Dawood, R.S.; Ahmed, K.T. (2015). Synthesis and characterization of new pyrazoline and isoxazoline derivatives based on fluorine. Tikrit J. Pure Sci.,20(2), 121-126.

Gunkara, O.T.; Ocal, N. (2018). Synthesis of new N-phthalimide substituted tricyclic imide containing isoxazoline and bispiro functional group as possible anticancer agents. J. Turkish Chem. Soc., 5(1), 73-48.

Hassan, S.Y. (2013). Synthesis, antibacterial and antifungal activity of some new pyrazoline and pyrazole derivatives. J. Molecules.18(3), 2683-2711. 
Joshi, V.D.; Kshirsagar, M.D.; Singhal, S. (2012). Synthesis and biological evaluation of some novel isoxazoles and benzodiazepines. J. Chem. and Pharmaceut. Research. 4(6), 3234-3238.

Kotla, V.V.; Dalavai, V.K.; Chunduri, V.R. (2012). Synthesis and biological activity studies of some novel pyrazoline derivatives. J. Der. Pharma. Chem., 4(5), 2003-2008.

Levai, A. (2005). Synthesis of chlorinated 3,5-diaryl-2-pyrazolines by the reaction of chlorochalcones with hydrazines. ARKIVOC (Archive for Organic Chemistry)344p.

Levai, A.; Katalin, E.K.; Jekö, J.(2007). "Synthesis of Tricyclic Fused Pyrazolines by the Reaction of 3-arylidenechromanones and 3-arylidene-1-thiochromanones with Hydrazine". ARKIVOC; (viii) pp.26-39.

Mntoya, A.; Quiroga, J.; Abonia, R.; Nogueras, M.; Cobo, J.; Insuasty, B. (2014). Synthesis and in vitro antitumor activity of a novel series of 2-pyrazoline derivatives bearing the 4-aryloxy-7chloroquinoline fragment. J. Molecules, 19, 18656-18675.

Nowakowska, Z.; Wyrzykiewicz, E.; Kedzia, B. (2001). Synthesis and antimicrobial properties of Nsubstituted derivatives of (E) -4-azachalcones. J. II Farmaco. 56(4), 325-329.

Patel, A.J.; Patel, M.P. (2016). Synthesis and antimicrobial studies of new pyrazoline/ isoxazoline derivatives bearing quinoline moiety using Ultrasound Irradiation. Indian J. Advances in Chem. Sci., 4(4), 409-420.

Rajanarendar, E.; Ramesh, P.; Kalyan Rao, E.; Mohan, G.; Srinivas, M. (2007)." p-TsOH Catalysed KSF Solid Supported Michael Addition with Substituted Isoxazoles and their Reductive Cyclisation to Isoxazolo[4,5b]azepines". ARKIVOC ; xiv: pp.266-75

Raoof, M.Y. (2005). Astudy on some azachalcones condensation reactions. Ph.D. Thesis, College of Scince. Mosul University, pp.15- 18.

Raoof, M.Y.; Saied, S.M.; AL.Gawady, M.S. (2013). Synthesis of some3-chloro-2,3-dimethyl-1phenylpyrazolidin-5-one (Chlorophenazone) Derivatives. Kirkuk University, J. Sci. Studies, 8(2), 34-42.

Shah, T.; Desai, V. (2007). Synthesis and antibacterial studies of some novel isoxazoline derivatives. $J$. Serb.Chem.Soc.,72(5), 443-449.

Sharma, S.; Kaur, S.; Bansal, T.; Gaba, J. (2014). Synthesis of bioactive pyrazoline derivatives. J. Chem. Sci. Trans., 3, 861-875.

Shih, T.L.; Liu, M.H.; Kuo, Ch.F.(2018). Halo substituted chalcones and azachalcones inhibited lipopoly saccharited stimulated Pro-Inflammatory responses through the TLR 4 -Mediated Pathway. Molecules, 23,597, www.mdpi.com.

Swamy, P.M.G.; Agasimundin, Y.S. (2008). Synthesis and antimicrobial screening of certain substituted chalcones and isoxazolines bearing hydroxyl benzofuran. Rasayan J. Chem., 1(2), 421-428.

Venkataraman, S.; Jaia, S.; Shah, K.; Upmanyu, N. (2010). Synthesis and biological activity of some novel pyrazolines. J. Acta Poloniae Pharmaceutica-Drug Research, 67(4), 361-366. 